Biogeosciences Discuss., 7, 2169-2193, 2010

www.biogeosciences-discuss.net/7/2169/2010/

(C) Author(s) 2010. This work is distributed under

This discussion paper is/has been under review for the journal Biogeosciences (BG). Please refer to the corresponding final paper in BG if available.

\title{
Climate driven decadal variations of biological production and plankton biomass in the equatorial Pacific Ocean: is this a regime shift?
}

Variations of biological production and plankton

biomass

X. J. Wang et al.

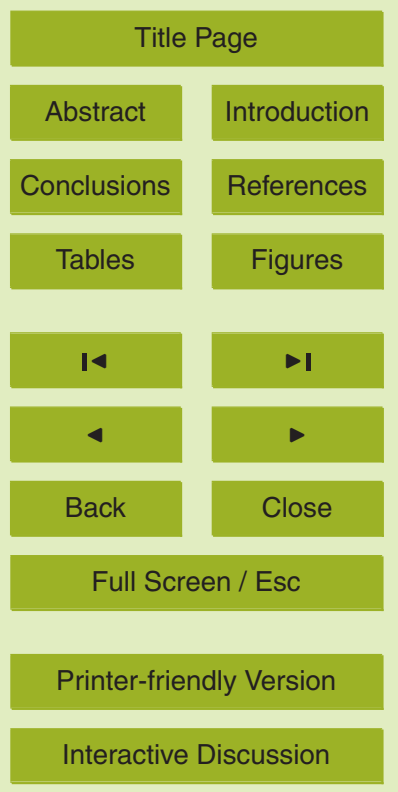

${ }^{1}$ Earth System Science Interdisciplinary Center, University of Maryland, College Park, MD 20740, USA

${ }^{2}$ Institut de Recherche pour le Développement, Centre de Nouméa, B.P. A5, 98848 Nouméa Cédex, New Caledonia, France

Received: 9 March 2010 - Accepted: 17 March 2010 - Published: 26 March 2010

Correspondence to: X. J. Wang (wwang@essic.umd.edu)

Published by Copernicus Publications on behalf of the European Geosciences Union. 


\section{Abstract}

Recent studies indicate strengthened trade winds and intensified upwelling in the tropical Pacific since the late 1990s, suggesting implications for the biogeochemical processes. We employed a fully coupled physical-biogeochemical model to test the hy5 pothesis that there were climate driven decadal variations in biogeochemical fields of the equatorial Pacific. We quantified changes in nitrate and iron concentrations, primary and secondary productions, and phytoplankton and zooplankton biomass between 1988-1996 and 1999-2007. Our modeling simulation showed that the intensified upwelling during 1999-2007 resulted in significant increases of nitrate and iron concentrations in the mixed layer of the central equatorial Pacific. In addition, the upwelling front moved westward, causing shifts of oligotrophic conditions to mesotrophic conditions in some parts of the western equatorial Pacific. As a result, there was an overall enhancement of biological activity in the western and central equatorial Pacific, leading to an increase in primary production and secondary production by $10-15 \%$ and

$1515-50 \%$, respectively. Our study also indicated that there were changes in ecosystem states in the equatorial Pacific Ocean, suggesting alternative new states with more zooplankton biomass during 1999-2007. Additionally, our study showed significant changes in seasonal variations of biogeochemical fields. Particularly, there was a much stronger seasonality in biological production and plankton biomass near the dateline during 1999-2007 relative to 1988-1996.

\section{Introduction}

The equatorial Pacific Ocean plays a large role in the global carbon cycle because of its vast expanse and significant air-sea $\mathrm{CO}_{2}$ exchange rates (Feely et al., 2002). In the physics' point view, the equatorial Pacific reveals two distinct regions: the upwelling region in the central and eastern Pacific and the warm pool to the west. These two regions are clearly separated by a front (Picaut et al., 2001; Le Borgne et al., 2002a).
BGD

$7,2169-2193,2010$

\section{Variations of \\ biological production \\ and plankton \\ biomass}

X. J. Wang et al.

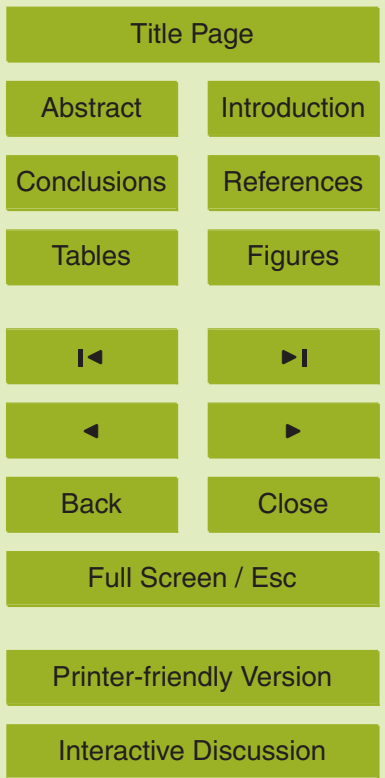


Under normal condition, the warm pool has deeper thermocline and nutricline, with extremely low nutrient concentrations in the mixed layer. In contrast, the upwelling region has shallower thermocline, and high macronutrient concentration in the surface waters. As a result, the warm pool often experiences oligotrophic conditions whereas

5 the upwelling region has mesotrophic conditions. Despite of the high macronutrient concentration, chlorophyll concentration is low in the central and eastern equatorial Pacific. Thus, this region is often referred to a High-Nutrient-Low-Chlorophyll (HNLC) region.

The equatorial Pacific Ocean is known to undergo significant physical changes at 10 interannual and decadal time scales, which are largely associated with the climate phenomenon, i.e., the El Niño/Southern Oscillation (ENSO) (McPhaden et al., 2006) and/or the Pacific Decadal Oscillation (PDO) (Zhang and McPhaden, 2006; Giese and Carton, 1999; Hasegawa and Hanawa, 2003). Both the ENSO and PDO cycles consist of a warm phase and a cold phase in terms of the sea surface temperature (SST) anomalies. During the warm phase, the trade winds generally weaken, thus reducing the driving force for upwelling of nutrient-rich waters into the surface layer. As a result, nutrient concentration is lower in the surface waters, which leads to lower phytoplankton growth. Conversely, the trade winds are intensified during the cold phase, producing stronger upwelling that brings more nutrients from the deep ocean into the surface waters, resulting in higher biological activity in the upper ocean.

There have been numerous studies addressing the interannual variability, which have indicated significant ENSO impacts on the equatorial Pacific Ocean physical processes (McPhaden, 2003; McPhaden et al., 2006), marine ecosystem dynamics (Strutton and Chavez, 2000; Wang et al., 2005) and biogeochemical processes (Chavez et al., 1999; Wang et al., 2006b; Feely et al., 2002; Le Borgne et al., 2002a). Particularly, an unusually large accumulation of phytoplankton was observed from the Sea-viewing Wide Field-of-view Sensor (SeaWiFS) imagery in the equatorial Pacific in mid-1998 following the recovery from the 1997-1998 El Niño (McClain et al., 2002; Murtugudde et al., 1999; Ryan et al., 2002). In addition, new production varied by a factor of two on

BGD

$7,2169-2193,2010$

\section{Variations of \\ biological production and plankton biomass}

X. J. Wang et al.

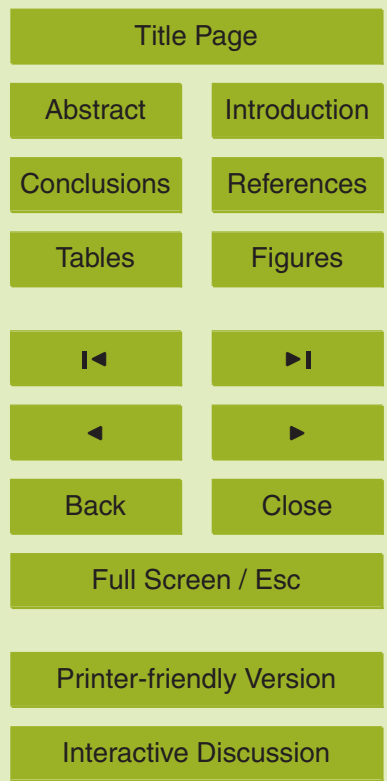


the equator during the transition from the warm phase to the cold phase (Turk et al., 2001). Both field (Strutton and Chavez, 2000) and modeling (Wang et al., 2005) studies showed a significant increase in the proportion of large cell phytoplankton species in the equatorial Pacific Ocean during the cold phase.

5 It appears that most of these changes deal with the 1997-1998 ENSO events. However, observations indicate that the tropical Pacific has experienced intensified shallow meridional overturning circulation and strong upwelling since 1998, reflecting a physical regime shift in association with the late 1990s change (i.e., a shift from a warm phase to a cold phase) in the PDO (McPhaden and Zhang, 2004). Coincidently, a so-called 10 biological regime shift, from a warm sardine regime to a cool anchovy regime, was discovered in the North Pacific in the late 1990s (Chavez et al., 2003). Interestingly, our earlier modeling study revealed that the ecosystem structure was systematically different (i.e., significant increase of zooplankton biomass relative to phytoplankton biomass) in the central and eastern equatorial Pacific between the period of 1998-2001 and the 15 period of 1990-1998 (Wang et al., 2005). These studies imply the possibility of largescale, systematic and long-lasting changes in biological processes in response to the late 1990s physical changes in the Pacific Ocean. However, there has been little focused analysis undertaken to address this issue, particularly in the equatorial Pacific, a region which plays a significant role in the global carbon cycle.

20 In this study, we employ a basin scale, fully coupled physical-biogeochemical model to study long-term impacts of climate condition on the biogeochemical fields in the equatorial Pacific Ocean. The coupled model has demonstrable capability for simulating spatial and temporal variations in physical fields (Murtugudde et al., 1996), ecosystem dynamics and biogeochemical fields in the tropical Pacific (Wang et al., 2005, 2006b, 2008, 2009). Particularly, the model has been validated in many biogeochemical fields, e.g., chlorophyll, nitrate, dissolved and particulate organic nitrogen (Wang et al., 2008, 2009). Similar to the approach of McPhaden and Zhang (2004), we compare the mean biogeochemical conditions for the two periods, prior to and post 1998. However, we extend our comparison to the longest possible duration and exclude the

\section{BGD}

7, 2169-2193, 2010

\section{Variations of \\ biological production and plankton biomass}

X. J. Wang et al.

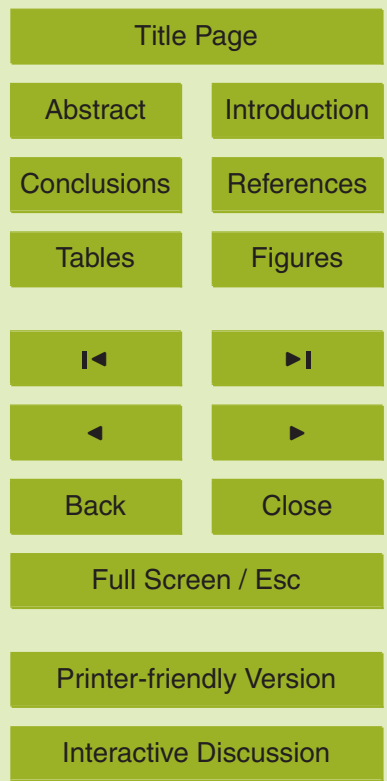


extreme period of 1997-1998, i.e., the 9-year period of 1999-2007 with the previous 9 -year period of 1988-1996. The objective of this study is to test the hypotheses that there are large-scale, systematic and long-lasting changes in nutrient conditions and biological activity in the equatorial Pacific.

The fully coupled 3-dimensional physical-biogeochemical model has been used extensively for studying the physical impacts on ecosystem dynamics and biogeochemical processes in the equatorial Pacific. The ocean general circulation model (OGCM) is a reduced-gravity, primitive-equation, sigma-coordinate model that is coupled to an advective atmospheric mixed layer model (Gent and Cane, 1989; Murtugudde et al., 1996). The OGCM has 20 vertical layers with variable thicknesses. The upper-most layer, the mixed layer, is determined by surface turbulent kinetic energy generation, dynamic instability mixing, and convective mixing to remove static instabilities (Chen et al., 1994). The model is set up for the Pacific domain between $30^{\circ} \mathrm{S}-30^{\circ} \mathrm{N}$ with zonal resolution of $1^{\circ}$, and variable meridional resolutions of $0.3-0.6^{\circ}$ between $15^{\circ} \mathrm{S}-15^{\circ} \mathrm{N}$ $\left(1 / 3^{\circ}\right.$ at latitudes $\left.<10^{\circ}\right)$, increasing to $2^{\circ}$ at the northern and southern boundaries. In the "sponge layer" $\left(10^{\circ}\right.$ band) near the boundaries, temperature, salinity, and nitrate are gradually relaxed back towards climatology.

The model is forced by solar radiation, cloudiness, surface wind stress, and precip20

itation. Air temperature and humidity are computed by the atmospheric mixed layer model. The solar radiation, precipitation, and cloudiness are climatological monthly means. The surface wind stresses are interannual, 6-day means from the National Centers for Environmental Prediction (NCEP) reanalysis (Kalnay et al., 1996). Windspeeds are computed from wind-stresses, resulting in interannual wind forcing, and

latent and sensible heat fluxes which are the most important surface forcings at interannual time-scales in the equatorial Pacific. Initial conditions are taken from the outputs of a climatological run which has been spun up for 30 years with initial conditions from

BGD

$7,2169-2193,2010$

\section{Variations of \\ biological production and plankton biomass}

X. J. Wang et al.

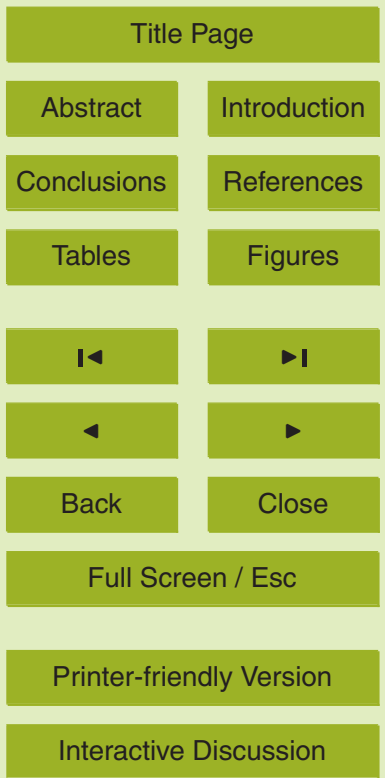

Interactive Discussion 
Levitus. We perform an interannual run starting from 1980, and use model outputs from the period of 1988-2007.

The biogeochemical model consists of ten components: seven biological pools and three nutrients (ammonium, nitrate, and dissolved iron). The biological pools include 5 dissolved organic nitrogen, and two sizes each (large and small) of phytoplankton, zooplankton and detritus. Small phytoplankton, large phytoplankton, small zooplankton and large zooplankton represent mainly picophytoplankton, diatoms (and other autotrophic plankton), micro- and meso-zooplankton, respectively (Le Borgne and Landry, 2003). Model structure, equations and biogeochemical parameters were given by 10 Wang et al. (2008). All biological components are carried in terms of their nitrogen equivalence, and computed in a similar manner to physical variables for all the layers. We apply a constant Redfield carbon to nitrogen $(\mathrm{C}: \mathrm{N})$ ratio $(6.625)$ to compute primary production (PP) and secondary production (SP).

Our modeling effort has included extensive use of observational data for model val15 idation in the equatorial Pacific. For instance, we have used large scale datasets of chlorophyll from water column in situ measurements and 10-years (1997-2007) satellite observations for assessment of our model skill (Wang et al., 2009). Here, we further demonstrate our model fidelity by comparing modeled PP rates with observations for the period of 1990-1996 when in situ data are made available (see Friedrichs et al., 2009). As shown in Table 1, there are good agreements between the independent observations and model results. For instance, for the western equatorial Pacific, the lowest and highest rates from the model are $23 \mathrm{mmol} \mathrm{C} \mathrm{m}^{-2} \mathrm{~d}^{-1}$ in 1990 and $90 \mathrm{mmol} \mathrm{C} \mathrm{m}^{-2} \mathrm{~d}^{-1}$ in 1996, respectively, which are similar to the observed rates of $21 \mathrm{mmol} \mathrm{C} \mathrm{m}^{-2} \mathrm{~d}^{-1}$ and $87 \mathrm{mmol} \mathrm{C} \mathrm{m}^{-2} \mathrm{~d}^{-1}$. Moreover, both observations and modeling results show that PP rates in 1996 along the equator are slightly lower in the central $\left(178^{\circ} \mathrm{W}-155^{\circ} \mathrm{W}\right)$ equatorial Pacific than in the western $\left(170^{\circ} \mathrm{E}-180^{\circ}\right)$ equatorial Pacific. The extensive model validations provide a solid base for the present quantitative study.

BGD

7, 2169-2193, 2010

\section{Variations of \\ biological production and plankton biomass}

X. J. Wang et al.






\section{Results}

\subsection{Changes in averaged physical and biogeochemical conditions}

Ocean physical characteristics are often described by mixed layer depth (MLD) and the $20^{\circ} \mathrm{C}$ isotherm depth (Z20). The former indicates the strength of vertical mixing in the

5 surface water whereas the latter represents the intensity of upwelling. Our modeling study shows an overall deepening in MLD and shoaling in Z20 during the period of 1999-2007 relative to the period of 1988-1996 (Fig. 1a, b). Particularly, considerable MLD deepening occurs near the dateline, suggesting potential enhancement in nutrient supply due to entrainment in this region. The model produces a shallower Z20 in the central equatorial Pacific and a deeper Z20 in the western warm pool for the period of 1999-2007, reflecting stronger upwelling and an increased east-west SST gradient post 1998 (McPhaden and Zhang, 2004).

Nitrate concentration in the mixed layer is generally higher across the basin during 1999-2007 than during 1988-1996 (Fig. 1c). However, modeled mixed layer concentration of dissolved iron shows an increase in the upwelling region, with the largest increase $\left(\sim 15 \mathrm{nmol} \mathrm{Fe} \mathrm{m}^{-3}\right)$ at the equator in the central equatorial Pacific (Fig. 1d). Our model simulation exhibits an overall increase in PP and SP from the period of 1988-1996 to the period of 1999-2007, with the largest increases near the dateline (Fig. 1e, f).

\subsection{Changes in ecosystem structure}

There is an overall but small increase in phytoplankton biomass over the upper $50 \mathrm{~m}$ of water column during the period of 1999-2007 relative to the period of 1988-1996 (Fig. 2a). Zooplankton biomass reveals much larger increases relative to phytoplankton biomass (Fig. 2b), leading to a pronounced increase in the ratio of zooplankton to phytoplankton (Fig. 2d). While the ratio of zooplankton to phytoplankton shows the largest increase near the dateline, the proportion of large phytoplankton in the commu-

\section{Variations of \\ biological production and plankton \\ biomass}

X. J. Wang et al.

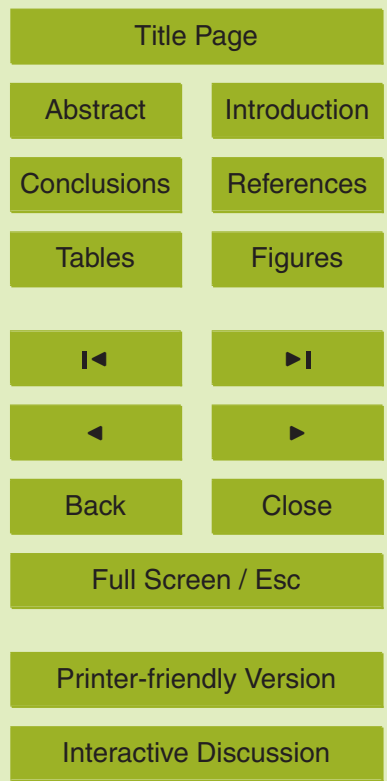


nity shows an increase mainly in the upwelling region with the greatest increase east of $150^{\circ} \mathrm{W}$ (Fig. 2c).

We evaluate the ecosystem states for the period of 1988-2007 in the equatorial Pacific (Fig. 2e). The phytoplankton biomass is relatively constant whereas the zoo5 plankton biomass shows large temporal variability. For the period prior to 1998, zooplankton biomass is close to phytoplankton biomass, which has been well observed in the equatorial Pacific (Le Borgne and Landry, 2003; Landry et al., 1997). However, for the period post 1998, zooplankton biomass are higher than phytoplankton biomass, indicating alterative states in the equatorial Pacific ecosystem.

\subsection{Changes in the HNLC conditions}

Figure 3 presents spatial distributions of chlorophyll and the differences between the two periods. The HNLC area (i.e., chlorophyll $>0.15 \mathrm{mg} \mathrm{m}^{-3}$ ) is larger during 19992007 (Fig. 3c) than during 1988-1996 (Fig. 3a), owing to the westward shift of the HNLC front. Overall, surface chlorophyll shows an increase across the basin, with the 5 largest increase (>0.05 $\mathrm{mg} \mathrm{m}^{-1}$ or $>30 \%$ ) near the dateline (Fig. 3e).

There is a well-defined deep chlorophyll maximum (DCM) in the equatorial Pacific, which is often placed at $\sim 100 \mathrm{~m}$ in the western warm pool and at $\sim 50 \mathrm{~m}$ in the upwelling region (Le Borgne et al., 2002a; Strutton and Chavez, 2000). Our model simulation shows that the DCM is located between the bottom of the mixed layer and the iso20 concentration depth of $110 \mathrm{nmol} \mathrm{Fe} \mathrm{m}^{-3}$ (Fe110) (Fig. 3b, d). The DCM is deeper and sharper in the oligotrophic region (i.e., chlorophyll $<0.15 \mathrm{mg} \mathrm{m}^{-3}$ ) during the period of 1988-1996 relative to 1999-2007. In general, chlorophyll has increased in the upper euphotic zone but decreased below $\sim 80 \mathrm{~m}$ over the later period. These changes reflect an overall weakening of DCM in association with alleviation of iron stress in the marine ecosystem (Holm-Hansen and Hewes, 2004).

\section{BGD}

7, 2169-2193, 2010

\section{Variations of \\ biological production \\ and plankton \\ biomass}

X. J. Wang et al.

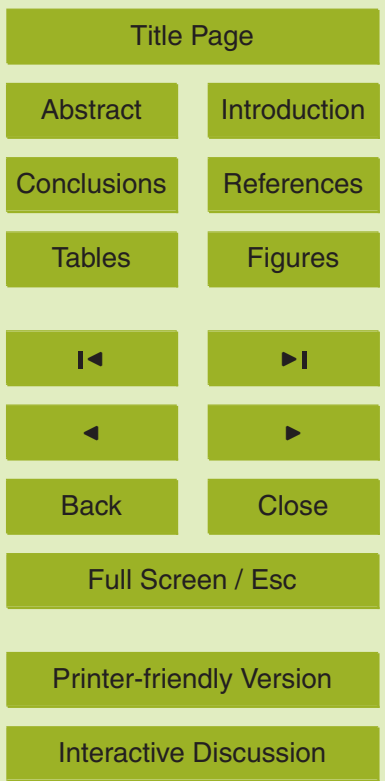




\subsection{Quantification of decadal changes}

To quantify the decadal changes in the biogeochemical fields, we carried out pooled two-sample $t$-tests for the central (CEP: $5^{\circ} \mathrm{N}-5^{\circ} \mathrm{S}, 180^{\circ}-135^{\circ} \mathrm{W}$ ) and the western equatorial Pacific (WEP: $5^{\circ} \mathrm{N}-5^{\circ} \mathrm{S}, 150^{\circ} \mathrm{E}-180^{\circ}$ ) (Table 2). For both regions, there

5 is no significant change in phytoplankton biomass. In the CEP, both iron and nitrate show a significant increase $(\sim 30 \%)$ in the mixed layer, which results in considerable increases in the integrated PP, SP and zooplankton biomass. Particularly, the integrated SP and zooplankton have increased by $~ 15 \%$ during the period of 1999-2007 relative to the period of 1988-1996. The WEP shows a larger degree of increase for

10 most of the biogeochemical parameters than the CEP. The only exception is that the mixed layer iron decreases from $6.6 \mathrm{nmol} \mathrm{m}^{-3}$ during $1988-1996$ to $5.2 \mathrm{nmol} \mathrm{m}^{-3}$ during 1999-2007 in the WEP. There are significant increases in the mixed layer nitrate (90\%), integrated PP (15\%), SP (50\%) and zooplankton (50\%). The high confidence levels $(P<0.001)$ for the most of the comparisons indicate systematic changes in the 15 mean biogeochemical conditions in the late 1990s.

\subsection{Changes in seasonality}

Seasonal anomalies of MLD (MLDA) and iron entrainment (FeEA) are presented in Fig. 4. During the period of 1988-1996, MLDA shows moderate seasonality with two peaks near the mid-year and end-year whereas FeEA reveals a considerable seasonal variation (higher values in the second half of the year) in the central equatorial Pacific. However, seasonal variations in MLDA and FeEA are much stronger during the period of 1999-2007 relative to the previous period. Moreover, MLDA and FeEA reveal a similar seasonality with one peak in boreal winter.

Model simulation also shows pronounced differences in the seasonal anomalies of integrated rates of PP (PPA) and SP (SPA) between the period of 1988-1996 and the period of 1999-2007 (Fig. 5). For the period of 1988-1996, the highest rates for both PPA and SPA are found in boreal fall in the central equatorial Pacific, but in spring in the

\section{Variations of \\ biological production and plankton biomass}

X. J. Wang et al.

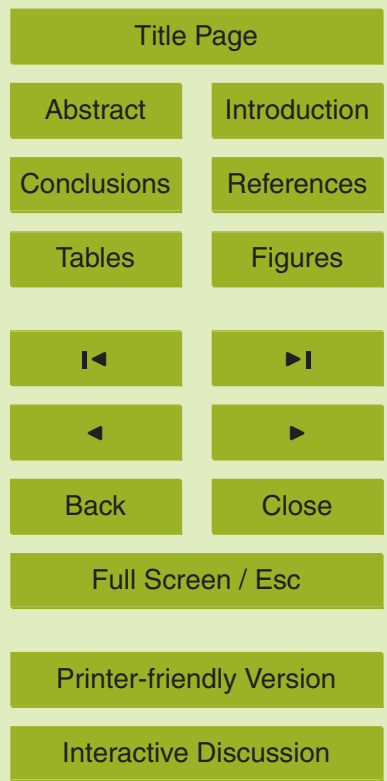


western warm pool. For the period of 1999-2007, the highest rates of PPA and SPA are found in boreal spring between $160^{\circ} \mathrm{E}$ and $160^{\circ} \mathrm{W}$. Similar to MLDA and FeEA, the seasonal variations of PPA and SPA are much stronger near the dateline during 1999-2007 than during 1988-1996.

$5 \quad$ Figure 6 presents the seasonal anomalies of phytoplankton biomass (PBA) and zooplankton biomass (ZBA). Overall, there is a small change in the seasonal variability of PBA between 1988-1996 and 1999-2007. However, there are significant differences in the seasonality of ZBA (Fig. 6b, d), which shows considerable similarity to those of PPA and SPA (Fig. 5).

\section{Discussions}

\subsection{Decadal variations in the equatorial Pacific ecosystem}

The equatorial Pacific Ocean has been characterized by (1) the dominance of picophytoplankton (counting for $\sim 90 \%$ of the total phytoplankton populations), and (2) the steady state of equal biomass between phytoplankton and zooplankton, achieved by

the balance between predation and growth (Le Borgne et al., 2002b). Particularly, abundance and biomass of picophytoplankton populations are largely controlled by balanced grazing losses to microzooplankton (Landry et al., 1997). In addition, it is known that iron is a primary limiting factor for phytoplankton growth in the upwelling region, and nitrate a limiting factor in the warm pool of the equatorial Pacific (Le Borgne et al., 2002b). For the upwelling region, the steady state may be disrupted (Le Borgne et al., 2002a) if there are changes in the conditions of iron limitation and/or grazing pressure (Wang et al., 2005).

A few studies have demonstrated significant changes in biological and/or chemical processes in the late 1990s in the Pacific Ocean, e.g., fishery (Chavez et al., 2003) and the carbon cycle (Feely et al., 2006). Our modeling study shows significant changes in biogeochemical conditions and ecosystem structure of the equatorial Pacific Ocean
BGD

7, 2169-2193, 2010

\section{Variations of \\ biological production \\ and plankton \\ biomass}

X. J. Wang et al.

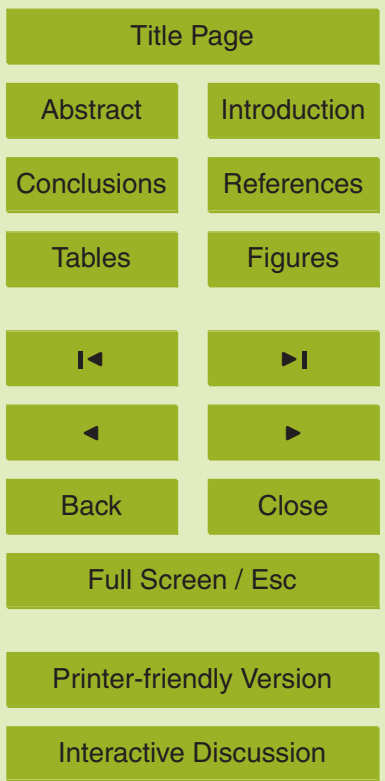


since the late 1990s. Particularly, the ecosystem states may have changed since the late 1990s. For the alternative new states, there are much more zooplankton biomass than phytoplankton biomass, and there are more large cells in the ecosystem community. These changes may reflect improved nutrient conditions associated with the 5 strengthened upwelling. Apparently, field studies are needed to evaluate these modeling results. In any case, our findings have the potential use for understanding the marine ecosystem dynamics, and the decadal variations.

\subsection{Climate impacts on the Pacific region}

The averaged Southern Oscillation index (SOI), calculated from the annual means of the standardized Tahiti minus Darwin sea-level pressures obtained from the Climate Prediction Centre (http://www.cpc.ncep.noaa.gov/data/indices/soi), changed from -0.37 during 1988-1996 to -0.08 during 1999-2007 (Table 3). The PDO index (http://jisao.washington.edu/pdo/PDO.latest) changed from 0.34 (representing a warm phase) to -0.08 (cold phase). Both indices point to an increasing trend in equatorial 5 upwelling for the period of 1999-2007. Interestingly, the PDO index changes the sign, which may imply a coincident timing of the regime shift (Chavez et al., 2003). Moreover, statistic analyses show a more significant difference in the PDO index than in the SOI, suggesting a long-lasting change that is distinct from the ENSO related events (Chen et al., 2002). While the mechanisms for the PDO phenomenon and the relation between 20 the PDO and ENSO variability remain open questions, our present analyses demonstrate decadal variations in biological processes associated with the late 1990s' PDO shift in the equatorial Pacific. Our analyses are based on model results that exclude the big 1997-1998 ENSO event. Statistics for comparison of two alternative periods (i.e., 1988-1997 and 1998-2007) yield the same conclusion.

25 There has been evidence of a wide range of changes in the late 1990s in the Pacific region. There are decadal-time-scale changes in the Pacific climate system (e.g., radiation budget, tropospheric humidity, and clouds), which are linked to the strengthening of the tropical Hadley and Walker circulation (Chen et al., 2002; Meehl et al.,
BGD

$7,2169-2193,2010$

\section{Variations of \\ biological production \\ and plankton \\ biomass}

X. J. Wang et al.

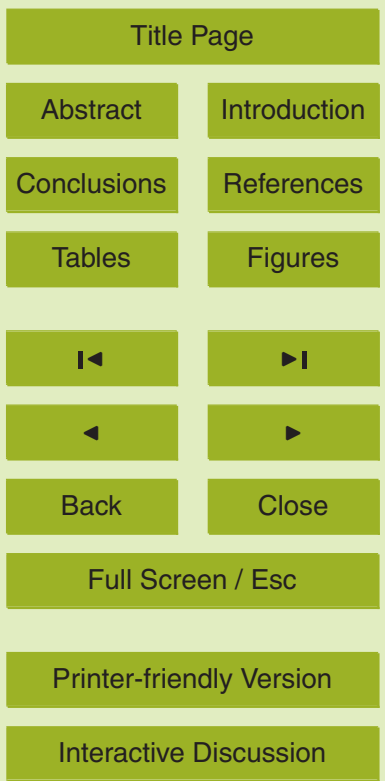


2009). These climate changes are likely responsible for the significant increase in trade wind strength (Table 3), which leads to enhanced upwelling and ocean circulation in the tropical Pacific Ocean (McPhaden and Zhang, 2004). Note that the stronger trade winds can also drive a stronger westward South Equatorial Current and hence a 5 slightly deeper thermocline in the western equatorial Pacific.

Our modeling study shows the central equatorial Pacific regions have experienced a significant increase in nutrient supply from the deeper ocean in association with the strengthened upwelling, which results in more nutrient-rich water in the upper ocean with two consequences. On the one hand, there is an increase in plankton biomass 10 and enhancement in biological production in the upwelling region. In association with these changes, the ecosystem structure alters with more secondary producer and an increase of large cells. On the other hand, the upwelling front moves westward, causing shifts of oligotrophic condition to mesotrophic conditions in some parts of the western equatorial Pacific. As a result, the whole basin has benefited with overall increases of nutrient concentration and biological production in the euphotic zone.

\subsection{Implications for the carbon cycle and future work}

The carbon cycle in the upper ocean is controlled by physical, biological, and chemical processes. While the $p \mathrm{CO}_{2}$ in the surface water is mainly determined by the SST and dissolved inorganic carbon (DIC) in the tropical upwelling regions, DIC and SST 20 have opposite effects (e.g., DIC increasing and SST decreasing the oceanic $p \mathrm{CO}_{2}$ during strong upwelling seasons). The overall spatial and temporal variations of the sea surface $p \mathrm{CO}_{2}$ may be dominated by physical processes in the tropical Pacific. However, biological activity plays an important role in modulating the variability of the sea surface $p \mathrm{CO}_{2}$, and determining the strength of the tropical Pacific $\mathrm{CO}_{2}$ source 25 (Cosca et al., 2003; Rixen et al., 2005; Sabine et al., 2000; Wang et al., 2006a; Sarma, 2006).

While strengthened winds have direct effects on the sea-air $\mathrm{CO}_{2}$ exchange rate (i.e., increasing gas exchange velocity), the recent changes in physical and biogeochemical

\section{BGD}

7, 2169-2193, 2010

\section{Variations of \\ biological production and plankton biomass}

X. J. Wang et al.

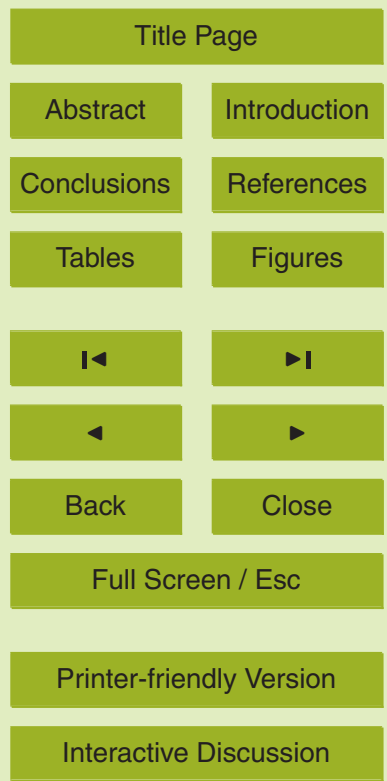

Interactive Discussion 
processes have complex influences on the carbon cycle in the equatorial Pacific. On the one hand, intensified upwelling brings cold, carbon-rich water into the surface, leading to a decrease in SST but an increase in DIC concentration. On the other hand, the enhanced biological activity, i.e., uptake of $\mathrm{CO}_{2}$, compensates the increase of DIC 5 concentration in the surface waters associated with intensified upwelling. This may explain the small increase in the amount of $\mathrm{CO}_{2}$-enriched water relative to considerable increase in wind speed post 1998 in the equatorial Pacific (Feely et al., 2006). Clearly, further studies are needed to provide detailed analyses of relative changes in both the biological and solubility pumps to assess the implications for the equatorial Pacific carbon cycle.

Acknowledgements. This work is supported by grants from the National Aeronautics and Space Administration. The authors wish to acknowledge use of the Ferret program for analysis and graphics in this paper. Ferret is a product of NOAA's Pacific Marine Environmental Laboratory (Information is available at http://ferret.pmel.noaa.gov/Ferret/).

\section{References}

Chavez, F. P., Strutton, P. G., Friederich, C. E., Feely, R. A., Feldman, G. C., Foley, D. C., and McPhaden, M. J.: Biological and chemical response of the equatorial Pacific Ocean to the 1997-98 El Nino, Science, 286, 2126-2131, 1999.

Chavez, F. P., Ryan, J., Lluch-Cota, S. E., and Niquen, M.: From anchovies to sardines and back: Multidecadal change in the Pacific Ocean, Science, 299, 217-221, 2003.

Chen, D., Rothstein, L. M., and Busalacchi, A. J.: A hybrid vertical mixing scheme and its application to tropical ocean models, J. Phys. Oceanogr., 24, 2156-2179, 1994.

Chen, J. Y., Carlson, B. E., and Del Genio, A. D.: Evidence for strengthening of the tropical general circulation in the 1990s, Science, 295, 838-841, 2002.

25 Cosca, C. E., Feely, R. A., Boutin, J., Etcheto, J., McPhaden, M. J., Chavez, F. P., and Strutton, P. G.: Seasonal and interannual $\mathrm{CO}_{2}$ fluxes for the central and eastern equatorial Pacific Ocean as determined from $\mathrm{fCO}_{2}$-SST relationships, J. Geophys. Res., 108(C8), 3278, doi:10.1029/2000JC000677, 2003.
BGD

$7,2169-2193,2010$

\section{Variations of \\ biological production \\ and plankton \\ biomass}

X. J. Wang et al.

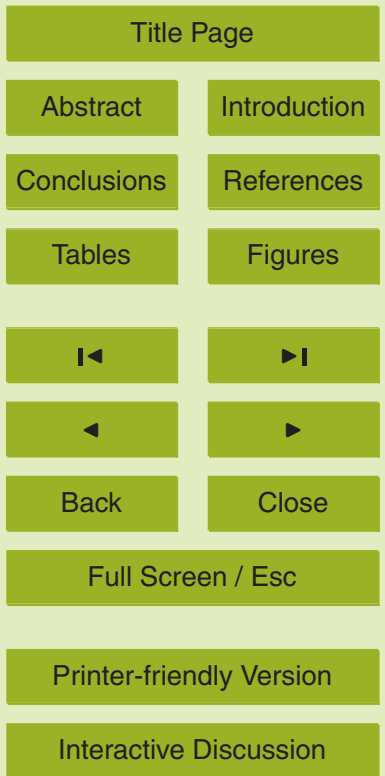


Feely, R. A., Boutin, J., Cosca, C. E., Dandonneau, Y., Etcheto, J., Inoue, H. Y., Ishii, M., Quéré, C. L., Mackey, D. J., McPhaden, M., Metzl, N., Poisson, A., and Wanninkhof, R.: Seasonal and interannual variability of CO2 in the equatorial Pacific, Deep Sea Res. II, 49, 2443-2469, 2002.

5 Feely, R. A., Takahashi, T., Wanninkhof, R., McPhaden, M. J., Cosca, C. E., Sutherland, S. C., and Carr, M. E.: Decadal variability of the air-sea CO2 fluxes in the equatorial Pacific Ocean, J. Geophys. Res., 111, C08S90, doi:10.1029/2005JC003129, 2006.

Friedrichs, M. A. M., Carr, M.-E., Barber, R. T., Scardi, M., Antoine, D., Armstrong, R. A., Asanuma, I., Behrenfeld, M. J., Buitenhuis, E. T., Chai, F., Christian, J. R., Ciotti, A. M., Doney, S. C., Dowell, M., Dunne, J., Gentili, B., Gregg, W., Hoepffner, N., Ishizaka, J., Kameda, T., Lima, I., Marra, J., Mélin, F., Moore, J. K., Morel, A., O’Malley, R. T., O’Reilly, J., Saba, V. S., Schmeltz, M., Smyth, T. J., Tjiputra, J., Waters, K., Westberry, T. K., and Winguth, A.: Assessing the uncertainties of model estimates of primary productivity in the tropical Pacific Ocean, J. Marine Syst., 76, 113-133, 2009.

Gent, P. R. and Cane, M. A.: A reduced gravity, primitive equation model of the upper Equatorial Ocean, J. Comput. Phys., 81, 444-480, 1989.

Giese, B. S. and Carton, J. A.: Interannual and decadal variability in the tropical and midlatitude Pacific Ocean, J. Climate, 12, 3402-3418, 1999.

Hasegawa, T. and Hanawa, K.: Decadal-scale variability of upper ocean heat content in the tropical Pacific, Geophys. Res. Lett., 30, 1272, doi:10.1029/2002GL016843, 2003.

Holm-Hansen, O. and Hewes, C. D.: Deep chlorophyll-a maxima (DCMs) in Antarctic waters - I. Relationships between DCMs and the physical, chemical, and optical conditions in the upper water column, Polar Biol., 27, 699-710, 2004.

Kalnay, E., Kanamitsu, M., Kistler, R., Collins, W., Deaven, D., Gandin, L., Iredell, M., Saha, S., White, G., Woollen, J., Zhu, Y., Chelliah, M., Ebisuzaki, W., Higgins, W., Janowiak, J., Mo, K. C., Ropelewski, C., Wang, J., Leetmaa, A., Reynolds, R., Jenne, R., and Joseph, D.: The NCEP/NCAR 40-year reanalysis project, B. Am. Meteorol. Soc., 77, 437-471, 1996.

Landry, M. R., Barber, R. T., Bidigare, R. R., Chai, F., Coale, K. H., Dam, H. G., Lewis, M. R., Lindley, S. T., McCarthy, J. J., Roman, M. R., Stoecker, D. K., Verity, P. G., and White, J. R.: Iron and grazing constraints on primary production in the central equatorial Pacific - an EqPac synthesis, Limnol. Oceanogr., 42, 405-418, 1997.

Le Borgne, R., Barber, R. T., Delcroix, T., Inoue, H. Y., Mackey, D. J., and Rodier, M.: Pacific warm pool and divergence: temporal and zonal variations on the equator and their effects on

BGD

7, 2169-2193, 2010

\section{Variations of \\ biological production \\ and plankton \\ biomass}

X. J. Wang et al.

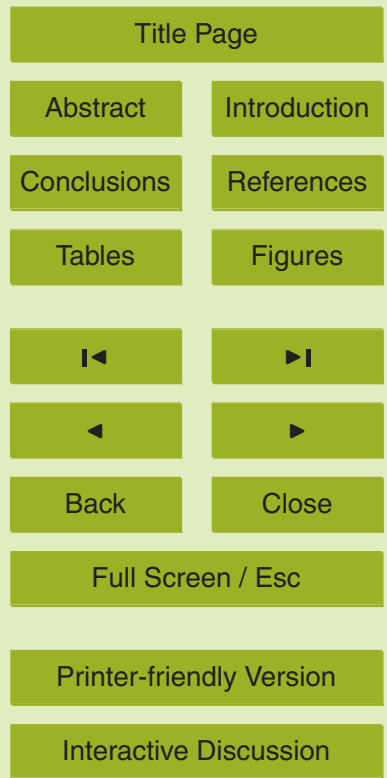


the biological pump, Deep-Sea Res. II, 49, 2471-2512, 2002a.

Le Borgne, R., Feely, R. A., and Mackey, D. J.: Carbon fluxes in the equatorial Pacific: a synthesis of the JGOFS programme, Deep-Sea Res. II, 49, 2425-2442, 2002b.

Le Borgne, R. and Landry, M. R.: EBENE: A JGOFS investigation of plankton variability and 5 trophic interactions in the equatorial Pacific (180 degrees), J. Geophys. Res., 108, 8136, doi:8110.1029/2001JC001252, 2003.

McClain, C. R., Christian, J. R., Signorini, S. R., Lewis, M. R., Asanuma, I., Turk, D., and Dupouy-Douchement, C.: Satellite ocean-color observations of the tropical Pacific Ocean, Deep Sea Res. II, 49, 2533-2560, 2002.

10 McPhaden, M. J.: Tropical Pacific Ocean heat content variations and ENSO persistence barriers, Geophys. Res. Lett., 30, 1480, doi:10.1029/2003GL016872, 2003.

McPhaden, M. J. and Zhang, D. X.: Pacific Ocean circulation rebounds, Geophys. Res. Lett., 31, L18301, doi:10.1029/2004GL020727, 2004.

McPhaden, M. J., Zebiak, S. E., and Glantz, M. H.: ENSO as an integrating concept in Earth 15 science, Science, 314, 1740-1745, doi:10.1126/science.1132588, 2006.

Meehl, G. A., Arblaster, J. M., Matthes, K., Sassi, F., and van Loon, H.: Amplifying the Pacific Climate System Response to a Small 11-Year Solar Cycle Forcing, Science, 325, 11141118, doi:10.1126/science.1172872, 2009.

Murtugudde, R., Seager, R., and Busalacchi, A.: Simulation of the tropical oceans with an ocean GCM coupled to an atmospheric mixed-layer model, J. Climate, 9, 1795-1815, 1996.

Murtugudde, R. G., Signorini, S. R., Christian, J. R., Busalacchi, A. J., McClain, C. R., and Picaut, J.: Ocean color variability of the tropical Indo-Pacific basin observed by SeaWiFS during 1997-1998, J. Geophys. Res., 104, 18351-18366, 1999.

Picaut, J., loualalen, M., Delcroix, T., Masia, F., Murtugudde, R., and Vialard, J.: The oceanic zone of convergence on the eastern edge of the Pacific warm pool: A synthesis of results and implications for El Nino-Southern Oscillation and biogeochemical phenomena, J. Geophys. Res., 106, 2363-2386, 2001.

Rixen, T., Guptha, M. V. S., and Ittekkot, V.: Deep ocean fluxes and their link to surface ocean processes and the biological pump, Prog. Oceanogr., 65, 240-259, 2005.

30 Ryan, J. P., Polito, P. S., Strutton, P. G., and Chavez, F. P.: Unusual large-scale phytoplankton blooms in the equatorial Pacific, Prog. Oceanogr., 55, 263-285, 2002.

Sabine, C. L., Wanninkhof, R., Key, R. M., Goyet, C., and Millero, F. J.: Seasonal $\mathrm{CO}_{2}$ fluxes in the tropical and subtropical Indian Ocean, Mar. Chem., 72, 33-53, 2000.

\section{BGD}

7, 2169-2193, 2010

\section{Variations of \\ biological production \\ and plankton \\ biomass}

X. J. Wang et al.

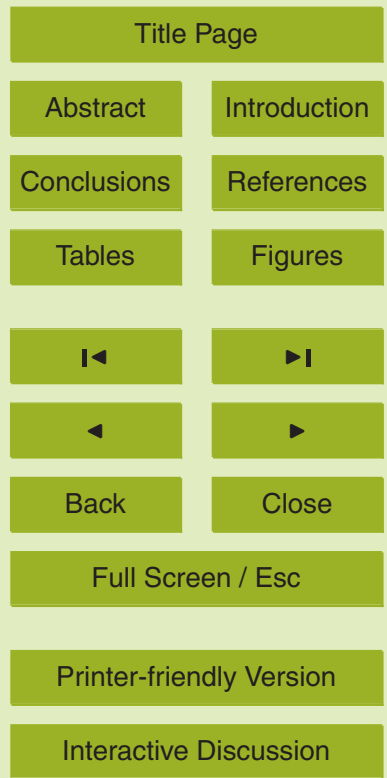


Sarma, V.: The influence of Indian Ocean Dipole (IOD) on biogeochemistry of carbon in the Arabian Sea during 1997-1998, J. Earth System Sci., 115, 433-450, 2006.

Strutton, P. G. and Chavez, F. P.: Primary productivity in the equatorial Pacific during the 19971998 El Nino, J. Geophys. Res., 105, 26089-26101, 2000.

5 Turk, D., McPhaden, M. J., Busalacchi, A. J., and Lewis, M. R.: Remotely sensed biological production in the equatorial Pacific, Science, 293, 471-474, 2001.

Wang, X. J., Christian, J. R., Murtugudde, R., and Busalacchi, A. J.: Ecosystem dynamics and export production in the central and eastern equatorial Pacific: A modeling study of impact of ENSO, Geophys. Res. Lett., 32, L02608, doi:02610.01029/02004GL021538, 2005.

10 Wang, X. J., Christian, J., Murtugudde, R., and Busalacchi, A.: Spatial and temporal variability of the surface water $p \mathrm{CO}_{2}$ and air-sea $\mathrm{CO}_{2}$ flux in the equatorial Pacific during 1980-2003: a basin-scale carbon model, J. Geophys. Res., 111, C07S04, doi:10.1029/2005JC002972, 2006a.

Wang, X. J., Christian, J. R., Murtugudde, R., and Busalacchi, A. J.: Spatial and temporal 15 variability in new production in the equatorial Pacific during 1980-2003: Physical and biogeochemical controls, Deep-Sea Res. II, 53, 677-697, 2006b.

Wang, X. J., Le Borgne, R., Murtugudde, R., Busalacchi, A. J., and Behrenfeld, M.: Spatial and temporal variations in dissolved and particulate organic nitrogen in the equatorial Pacific: biological and physical influences, Biogeosciences, 5, 1705-1721, 2008,

20 http://www.biogeosciences.net/5/1705/2008/.

Wang, X. J., Behrenfeld, M., Le Borgne, R., Murtugudde, R., and Boss, E.: Regulation of phytoplankton carbon to chlorophyll ratio by light, nutrients and temperature in the Equatorial Pacific Ocean: a basin-scale model, Biogeosciences, 6, 391-404, 2009, http://www.biogeosciences.net/6/391/2009/.

Zhang, D. X. and McPhaden, M. J.: Decadal variability of the shallow Pacific meridional overturning circulation: Relation to tropical sea surface temperatures in observations and climate change models, Ocean Modell., 15, 250-273, doi:10.1016/j.ocemod.2005.12.005, ISSN 1463-5003, 2006.

BGD

$7,2169-2193,2010$

\section{Variations of \\ biological production \\ and plankton \\ biomass}

X. J. Wang et al.

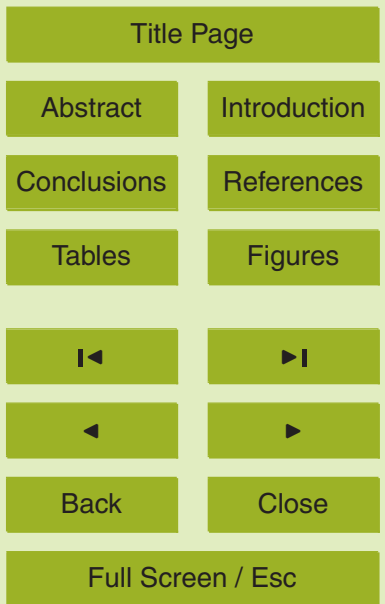

Printer-friendly Version

Interactive Discussion 
BGD

7, 2169-2193, 2010

Variations of biological production and plankton

Table 1. Averaged primary productivity $\left(\mathrm{mmol} \mathrm{C}^{-2} \mathrm{~d}^{-1}\right)$ from model and data.

\begin{tabular}{|c|c|c|c|c|}
\hline Year & Lat. & Long. & Model & Data* $^{*}$ \\
\hline \multicolumn{5}{|c|}{ Central and eastern equatorial Pacific } \\
\hline $\begin{array}{l}1990 \\
1992 \\
1995 \\
1996\end{array}$ & $\begin{array}{l}8^{\circ} \mathrm{N}-4^{\circ} \mathrm{S} \\
10^{\circ} \mathrm{N}-10^{\circ} \mathrm{S} \\
4^{\circ} \mathrm{S}-7^{\circ} \mathrm{S} \\
0^{\circ}\end{array}$ & $\begin{array}{l}140^{\circ} \mathrm{W}-110^{\circ} \mathrm{W} \\
170^{\circ} \mathrm{W}-95^{\circ} \mathrm{W} \\
110^{\circ} \mathrm{W}-105^{\circ} \mathrm{W} \\
178^{\circ} \mathrm{W}-155^{\circ} \mathrm{W}\end{array}$ & $\begin{array}{l}66 \\
46 \\
41 \\
86\end{array}$ & $\begin{array}{l}58 \\
54 \\
57 \\
81\end{array}$ \\
\hline \multicolumn{5}{|c|}{ Western equatorial Pacific } \\
\hline $\begin{array}{l}1990 \\
1996\end{array}$ & $\begin{array}{l}10^{\circ} \mathrm{N}-10^{\circ} \mathrm{S} \\
0^{\circ}\end{array}$ & $\begin{array}{l}150^{\circ} \mathrm{E}-180^{\circ} \\
170^{\circ} \mathrm{E}-180^{\circ}\end{array}$ & $\begin{array}{l}23 \\
90\end{array}$ & $\begin{array}{l}21 \\
87\end{array}$ \\
\hline
\end{tabular}

${ }^{*}$ Data are averages from Friedrichs et al. (2009).

\section{biomass}

X. J. Wang et al.

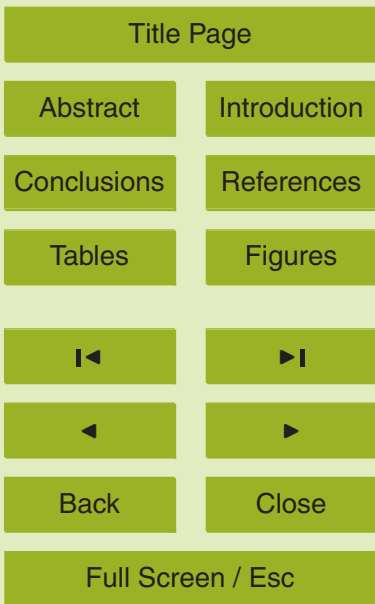

Printer-friendly Version

Interactive Discussion 
Table 2. The pooled two-sample $t$ tests for the means of mixed layer nitrate and iron concentrations, and integrated primary production (PP), secondary production (SP) and phytoplankton and zooplankton between 1988-1996 and 1999-2007 for central (CEP) and western (WEP) equatorial Pacific regions.

\begin{tabular}{|c|c|c|c|c|c|}
\hline Parameter & Unit & $1988-1996$ & 1999-2007 & Increase & $t$ value \\
\hline \multicolumn{6}{|c|}{$-\operatorname{CEP}\left(5^{\circ} \mathrm{N}-5^{\circ} \mathrm{S}, 180^{\circ}-135^{\circ} \mathrm{W}\right)-$} \\
\hline Nitrate & $\mathrm{mmol} \mathrm{m} \mathrm{m}^{-3}$ & 3.5 & 14.6 & 1.1 & $5.8^{* * *}$ \\
\hline Iron & $\mathrm{nmol} \mathrm{m}{ }^{-3}$ & 16.3 & 20.5 & 4.2 & $4.5^{\star \star \star}$ \\
\hline PP & $\mathrm{mmolCm} \mathrm{m}^{-2} \mathrm{~d}^{-1}$ & 55.6 & 61.3 & 5.7 & $4.9^{\star \star *}$ \\
\hline SP & $\mathrm{mmolCm} \mathrm{m}^{-2} \mathrm{~d}^{-1}$ & 29.1 & 33.7 & 4.6 & $5.1^{\star * *}$ \\
\hline Phytoplankton & $\mathrm{mmol} \mathrm{N} \mathrm{m}^{-2}$ & 19.1 & 19.0 & -0.1 & 0.9 \\
\hline Zooplankton & $\mathrm{mmol} \mathrm{N} \mathrm{m}^{-2}$ & 21.1 & 24.3 & 3.2 & $4.9^{\star \star \star}$ \\
\hline \multicolumn{6}{|c|}{$\longrightarrow$ WEP $\left(5^{\circ} \mathrm{N}-5^{\circ} \mathrm{S}, 150^{\circ} \mathrm{E}-180^{\circ}\right)-$} \\
\hline Nitrate & $\mathrm{mmol} \mathrm{m}{ }^{-3}$ & 0.7 & 1.3 & 0.6 & $5.9^{\star \star \star}$ \\
\hline Iron & $\mathrm{nmol} \mathrm{m} \mathrm{m}^{-3}$ & 6.6 & 5.2 & -1.4 & $3.5^{\star \star *}$ \\
\hline $\mathrm{PP}$ & $\mathrm{mmolCm} \mathrm{m}^{-2} \mathrm{~d}^{-1}$ & 27.8 & 31.8 & 4.0 & $3.9^{* * *}$ \\
\hline SP & $\mathrm{mmolCm} \mathrm{m}^{-2} \mathrm{~d}^{-1}$ & 6.1 & 9.5 & 3.4 & $3.8^{\star \star \star}$ \\
\hline Phytoplankton & $\mathrm{mmol} \mathrm{N} \mathrm{m}^{-2}$ & 19.7 & 19.9 & 0.2 & 1.1 \\
\hline Zooplankton & $\mathrm{mmol} \mathrm{N} \mathrm{m}^{-2}$ & 4.3 & 6.8 & 2.6 & $3.9^{\star \star \star}$ \\
\hline
\end{tabular}

Significance of $t$ value is marked with one $(p<0.05)$, two $(p<0.01)$ and three $(p<0.001)$ asterisks.
BGD

$7,2169-2193,2010$

\section{Variations of \\ biological production and plankton \\ biomass}

X. J. Wang et al.

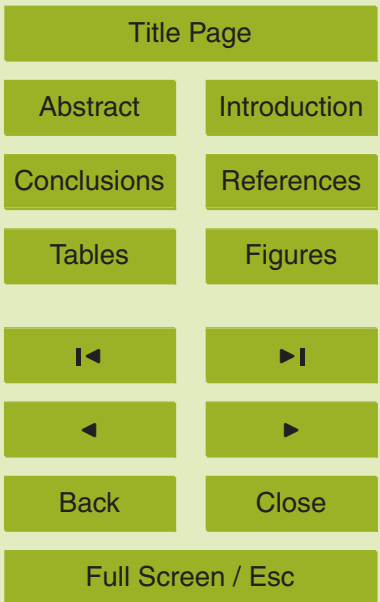

Printer-friendly Version

Interactive Discussion 
BGD

$7,2169-2193,2010$

Variations of

biological production and plankton

biomass

Table 3. Mean, standard deviation (s.d.) and $t$ tests for the SOI, PDO index, and zonal (ZWS) and meridional (MWS) wind stresses between 1988-1996 and 1999-2007 for western and central equatorial Pacific $\left(5^{\circ} \mathrm{N}-5^{\circ} \mathrm{S}, 150^{\circ} \mathrm{E}-135^{\circ} \mathrm{W}\right)$.

\begin{tabular}{llrrrr}
\hline Variable & Unit & $1988-1996$ & $1999-2007$ & Increase & $t$ value \\
\hline SOI & $\mathrm{N} / \mathrm{A}$ & -0.372 & -0.084 & 0.288 & $2.07^{*}$ \\
PDO index & $\mathrm{N} / \mathrm{A}$ & 0.339 & -0.078 & -0.417 & $3.25^{\star *}$ \\
ZWS & $\mathrm{N} \mathrm{m}^{-2}$ & -0.033 & -0.039 & -0.006 & $3.04^{* *}$ \\
MWS & $\mathrm{N} \mathrm{m}^{-2}$ & -0.003 & -0.007 & -0.004 & $3.21^{* *}$ \\
\hline
\end{tabular}

Significance of $t$ value is marked with one $(p<0.05)$, two $(p<0.01)$ and three $(p<0.001)$ asterisks.
Title Page

Abstract Introduction

Conclusions References

Tables Figures

X. J. Wang et al.

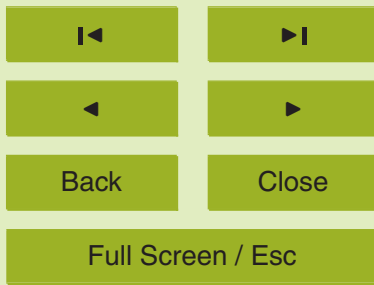

Printer-friendly Version 
BGD

$7,2169-2193,2010$ (a) $\operatorname{MLD}(m)$
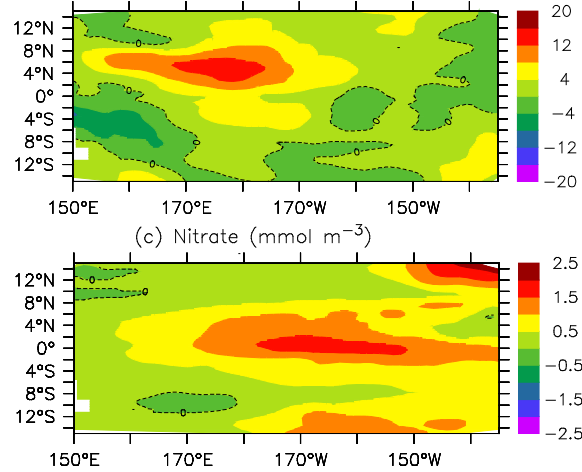

(e) $P^{\prime}\left(m m o l c m^{-2} d^{-1}\right)$



(c) Nitrate $\left(\mathrm{mmol} \mathrm{m}^{-3}\right)$ (b) $220(\mathrm{~m})$

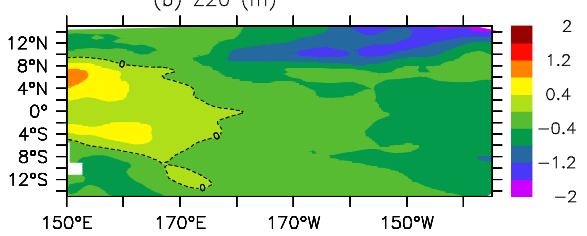

(d) Iron $\left(\mathrm{nmol} \mathrm{m}^{-3}\right)$

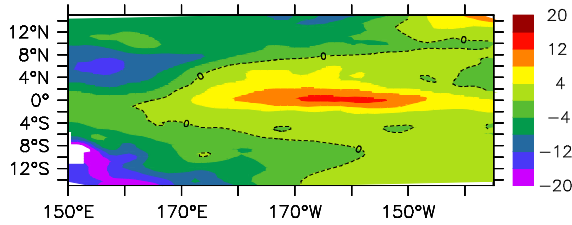

(f) $S P\left(m m o l c m^{-2} d^{-1}\right)$

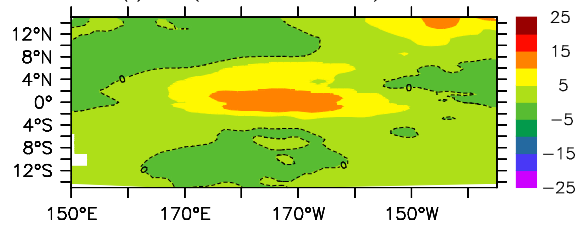

Fig. 1. Differences (1999-2007 minus 1988-1996) of (a) the mixed layer depth (MLD), (b) the $20^{\circ} \mathrm{C}$ isotherm depth (Z20), (c) the mixed layer nitrate concentration, (d) the mixed layer iron concentration, (e) the integrated primary production (PP) over 0-120 m, and (f) the integrated secondary production (SP) over 0-120 m.

\section{Variations of \\ biological production and plankton \\ biomass}

X. J. Wang et al.

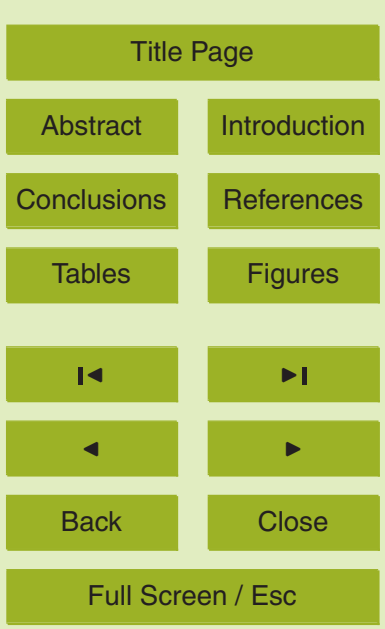

Printer-friendly Version

Interactive Discussion 
(a) Phytoplankton ( $m$ mol $\mathrm{N} \mathrm{m}^{-3}$ )

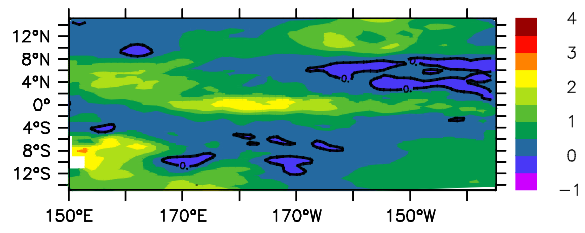

(c) $\mathrm{PL} / \mathrm{P}$ ratio

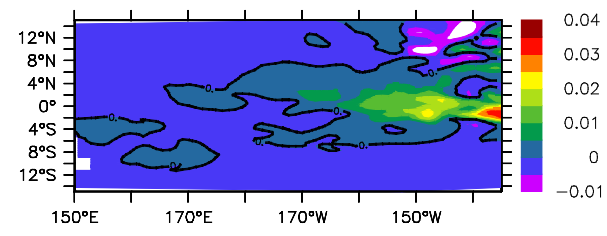

(e)

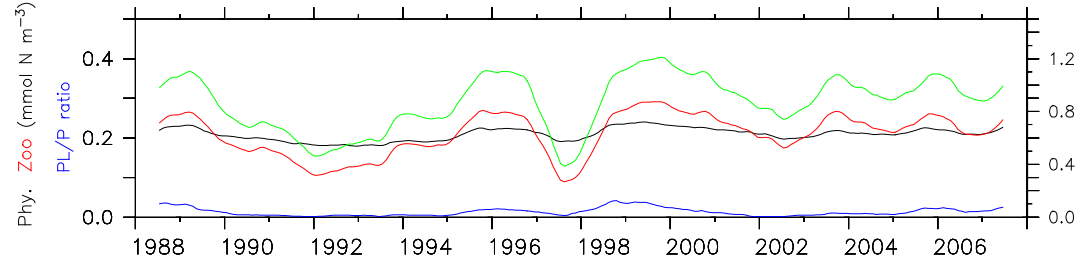

Fig. 2. Differences (1999-2007 minus 1988-1996) in integrated (0-50 m) biomass of (a) phytoplankton, (b) zooplankton, and ratios of (c) large phytoplankton to total phytoplankton (PL/P), and (d) zooplankton to phytoplankton (Zoo/Phy ratio). (e) Time series of biomass of phytoplankton (black) and zooplankton (red), PL/P ratio (blue) and Zoo/Phy ratio (green) averaged over $0-50 \mathrm{~m}$ for the box of $150^{\circ} \mathrm{E}-135^{\circ} \mathrm{W}, 5^{\circ} \mathrm{N}-5^{\circ} \mathrm{S}$.
BGD

7, 2169-2193, 2010

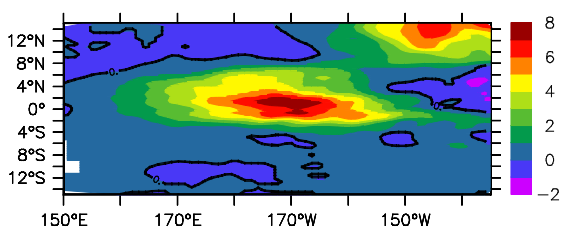

(d) Zoo/Phy ratio

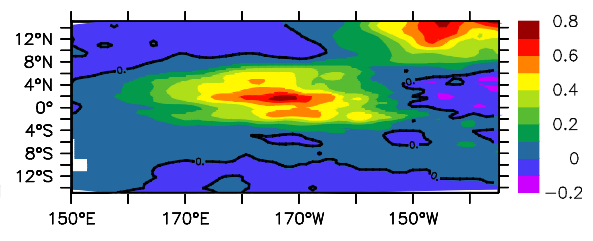

X. J. Wang et al.

\section{Title Page}

Abstract

Introduction

Conclusions

References

Tables

Figures

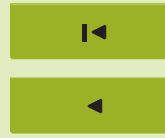

$\rightarrow$ I

Back

Close

\section{Full Screen / Esc}

Printer-friendly Version

Interactive Discussion 
BGD

$7,2169-2193,2010$ (a) $1988-1996$

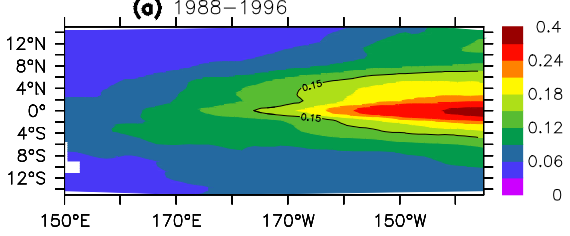

(c) $1999-2007$

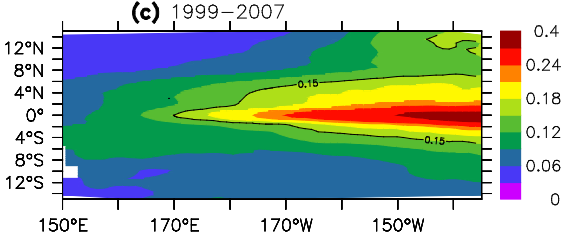

(e) 1999-2007 minus 1988-1996

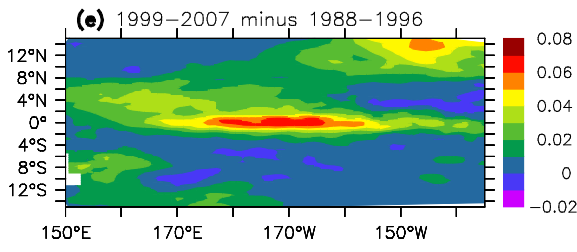

$150^{\circ} \mathrm{E} \quad 170^{\circ} \mathrm{E} \quad 170^{\circ} \mathrm{W} \quad 150^{\circ} \mathrm{W}$

Fig. 3. Averaged chlorophyll ( $\mathrm{mg} \mathrm{m}^{-3}$ ) in the mixed layer (left panel) and over $5^{\circ} \mathrm{N}-5^{\circ} \mathrm{S}$ (right panel) for (a) and (b) 1988-1996, (c) and (d) 1999-2007, and (e) and (f) the difference (19992007 minus 1988-1996). (b) $1988-1996$

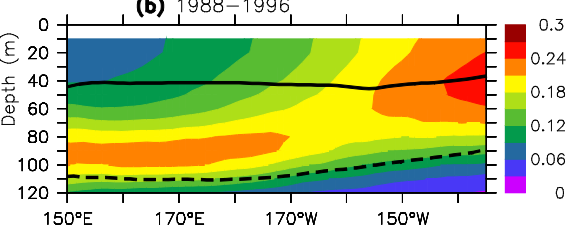

(d) $1999-2007$

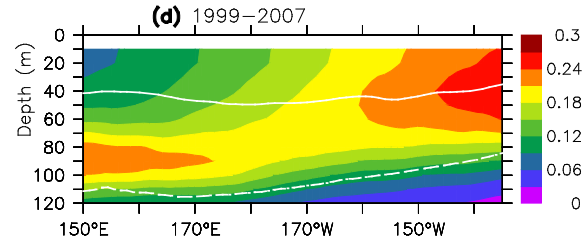

(f) $1999-2007$ minus $1988-1996$

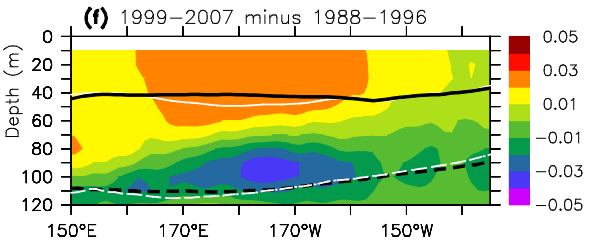

\section{Abstract}

Conclusions

Tables

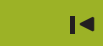

Title Page

Variations of olankton biomass

X. J. Wang et al.

\section{Back}

Close

\section{Full Screen / Esc}

Printer-friendly Version

Interactive Discussion 
BGD
$\operatorname{MLDA}(m)$

(a) $1988-1996$

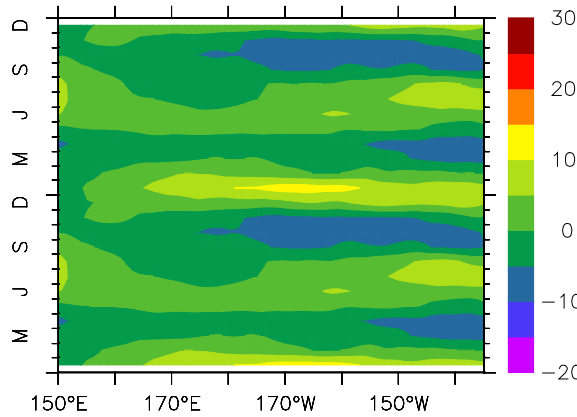

(c) $1999-2007$

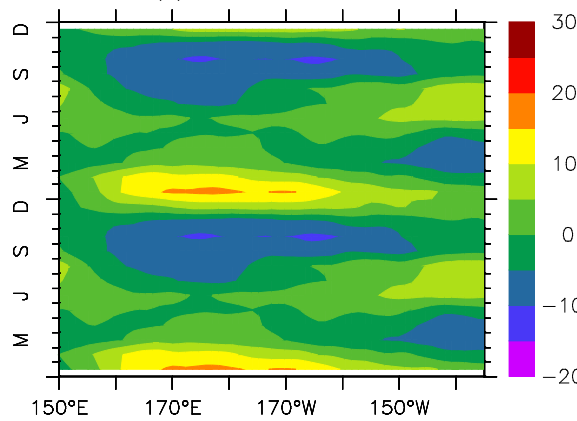

FeEA (nmol Fe $\left.m^{-2} d^{-1}\right)$

(b) $1988-1996$

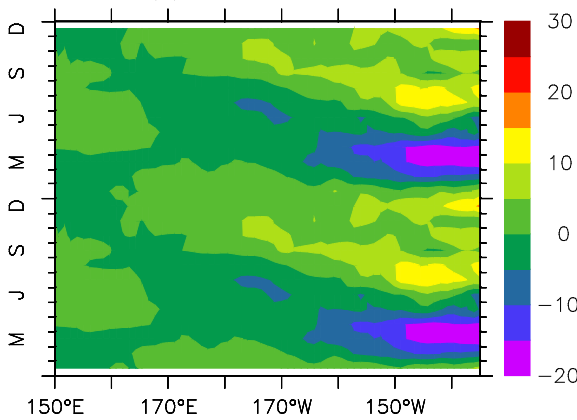

(d) 1999-2007

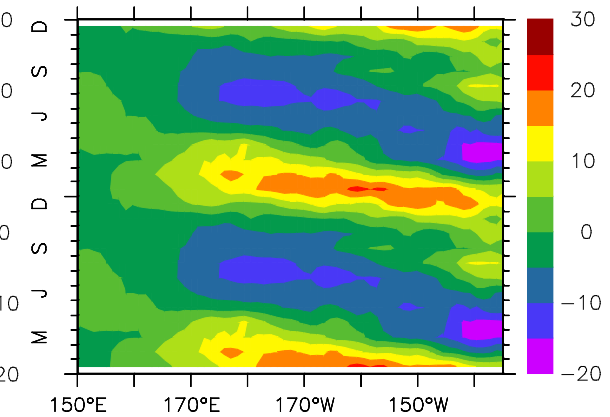

Fig. 4. Seasonal anomalies (plotted over two years) of the mixed layer depth (MLDA: left side) and iron entrainment (FeEA: right side) over $5^{\circ} \mathrm{N}-5^{\circ} \mathrm{S}$. (a) and (b) for 1988-1996, and (c) and (d) for 1999-2007.
$7,2169-2193,2010$

Variations of

biological production and plankton

biomass

X. J. Wang et al.

Title Page

\section{Abstract}

Conclusions

\section{Tables}

14

4

Back
Introduction

References

Figures

$>$ I

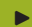

Close
Full Screen / Esc

Printer-friendly Version

Interactive Discussion 
BGD
PPA (mmol $\mathrm{N} \mathrm{m}^{-2}$ )

(a) $1988-1996$

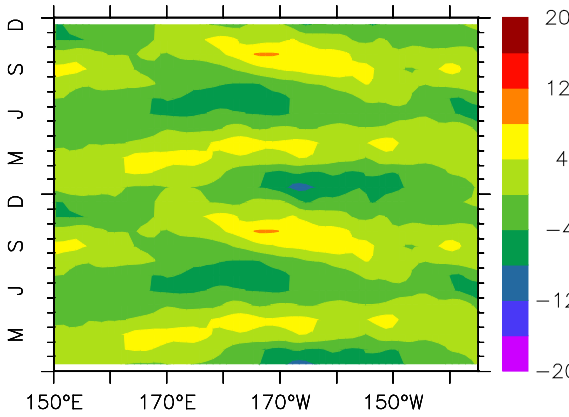

(c) $1999-2007$

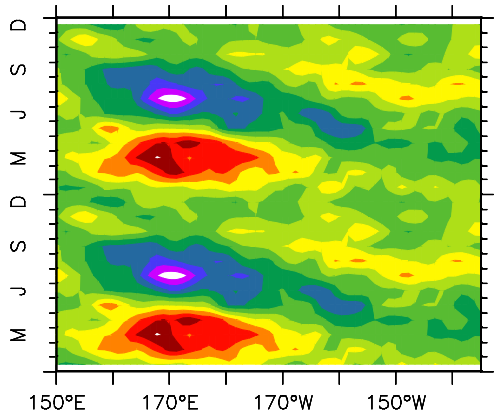

SPA ( $m$ mol $\mathrm{N} \mathrm{m}^{-2}$ )

(b) $1988-1996$

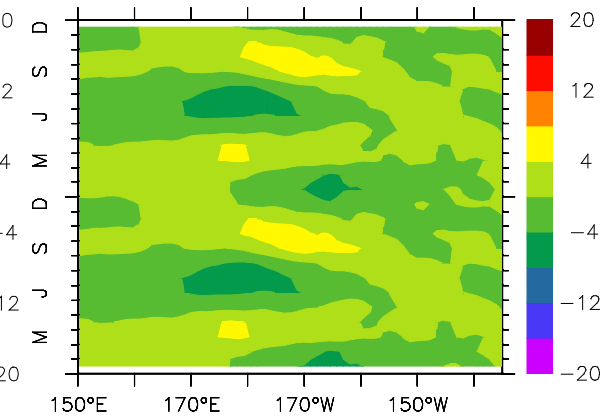

(d) $1999-2007$

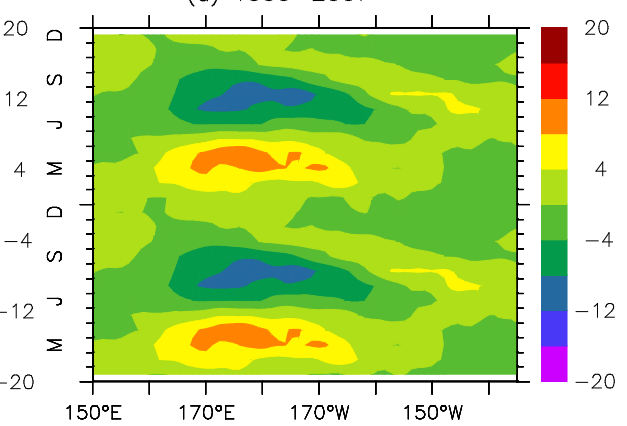

Fig. 5. Seasonal anomalies (plotted over two years) of integrated $(0-120 \mathrm{~m})$ primary productivity (PPA: left side) and secondary production (SPA: right side) over $5^{\circ} \mathrm{N}-5^{\circ} \mathrm{S}$. (a) and (b) for 1988-1996, and (c) and (d) for 1999-2007.

biomass

Title Page

$7,2169-2193,2010$

Variations of

biological production and plankton

X. J. Wang et al.

\section{Abstract}

Conclusions

Tables

14

Back

Full Screen / Esc

Printer-friendly Version

Interactive Discussion 
BGD
PBA (mmol $\mathrm{N} \mathrm{m}^{-2}$ )

(a) $1988-1996$

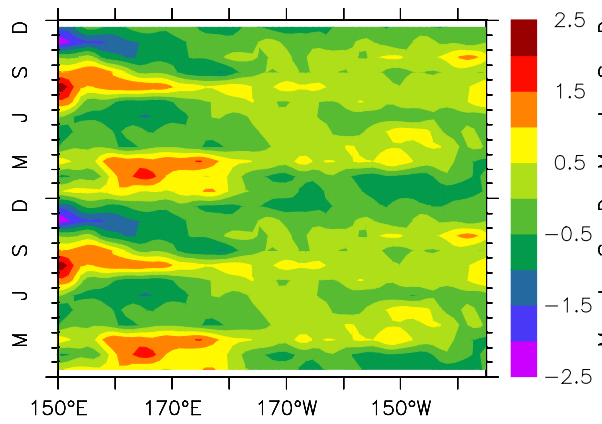

(c) 1999-2007



ZBA (mmol $\mathrm{Nm}^{-2}$ )

(b) $1988-1996$

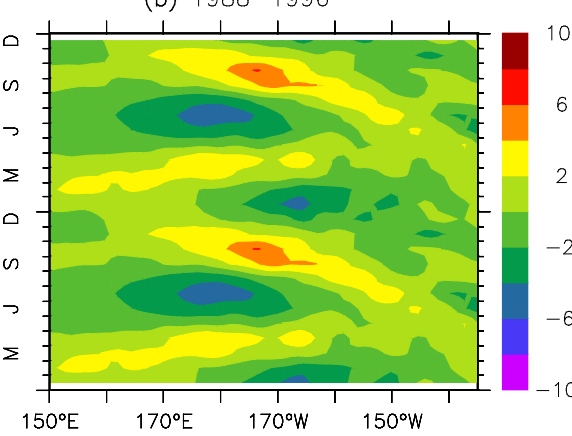

(d) $1999-2007$

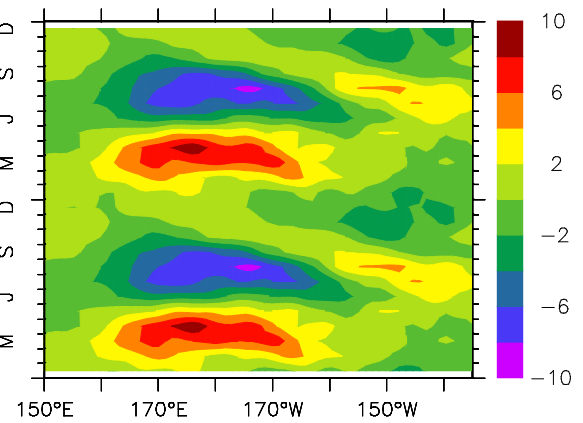

Fig. 6. Seasonal anomalies (plotted over two years) of integrated $(0-50 \mathrm{~m})$ phytoplankton biomass (PBA: left side) and zooplankton biomass (ZBA: right side) over $5^{\circ} \mathrm{N}-5^{\circ} \mathrm{S}$. (a) and (b) for 1988-1996, and (c) and (d) for 1999-2007.
$7,2169-2193,2010$

\section{Variations of biological production and plankton biomass}

X. J. Wang et al.

\section{Title Page}

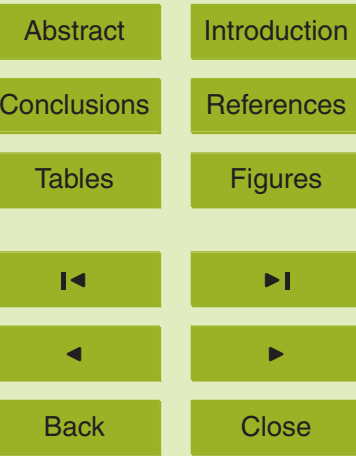

Full Screen / Esc

Printer-friendly Version

Interactive Discussion 